\title{
Peroxisome Proliferator-Activated Receptor $\gamma$ and Cardiovascular Diseases
}

\author{
Hiroyuki Takano, MD; Issei Komuro, MD
}

\begin{abstract}
Peroxisome proliferator-activated receptors (PPARs) are members of the nuclear receptor superfamily and form heterodimers with retinoid X receptor. Three PPAR isoforms have been isolated and termed $\alpha, \beta$ (or $\delta$ ) and $\gamma$. Although PPAR $\gamma$ is expressed predominantly in adipose tissue and associated with adipocyte differentiation and glucose homeostasis, PPAR $\gamma$ is also present in a variety of cell types. Synthetic antidiabetic thiazolidinediones (TZDs) are well known as ligands and activators for PPAR $\gamma$. After it was reported that activation of PPAR $\gamma$ suppressed production of pro-inflammatory cytokines in activated macrophages, medical interest in PPAR $\gamma$ has grown and there has been a huge research effort. PPAR $\gamma$ is currently known to be implicated in various human chronic diseases such as diabetes mellitus, atherosclerosis, rheumatoid arthritis, inflammatory bowel disease, and Alzheimer's disease. Many studies suggest that TZDs not only ameliorate insulin sensitivity, but also have pleiotropic effects on many tissues and cell types. Although activation of PPAR $\gamma$ seems to have beneficial effects on cardiovascular diseases, the mechanisms by which PPAR $\gamma$ ligands prevent their development are not fully understood. Recent data about the actions and its mechanisms of PPAR $\gamma$-dependent pathway in cardiovascular diseases are discussed here. (Circ J 2009; 73: 214-220)
\end{abstract}

Key Words: Atherosclerosis; Cardiac hypertrophy; Heart failure; PPAR $\gamma$; Thiazolidinedione

$\mathbf{P}$ eroxisome proliferator-activated receptors (PPARs) are transcription factors belonging to the nuclear receptor superfamily that heterodimerize with the retinoid $\mathrm{X}$ receptor (RXR) and bind to specific response elements termed PPAR responsive elements (PPREs) in target gene promoters. The PPREs are direct repeats of the hexameric consensus sequence AGGTCA, separated by 1 nucleotide. These nuclear receptors are ligand-dependent transcription factors, and activation of target gene transcription depends on the binding of the ligand to the receptor. PPARs have 3 isoforms, $\alpha, \beta$ (or $\delta$ ) and $\gamma$. PPAR $\alpha$ regulates genes involved in fatty acid oxidation, whereas PPAR $\gamma$ promotes adipocyte differentiation and glucose homeostasis. The main function of PPAR $\beta / \delta$ has yet to be ascertained, but involvement in the regulation of fatty acid oxidation seems likely. PPAR $\alpha$ is present mainly in the liver, kidney, and muscle, whereas PPAR $\gamma$ is expressed predominantly in adipose tissue. PPAR $\beta / \delta$ is almost ubiquitously expressed. It was recently demonstrated that PPAR $\gamma$ is also expressed in a variety of cell types. After it was reported that activation of PPAR $\gamma$ suppresses production of inflammatory cytokines in activated macrophages, medical interest in PPAR $\gamma$ has grown, along with a huge research effort.

(Received November 17, 2008; accepted December 8, 2008; released online January 8, 2009)

Department of Cardiovascular Science and Medicine, Chiba University Graduate School of Medicine, Chiba, Japan

Mailing address: Hiroyuki Takano, MD, Department of Cardiovascular Science and Medicine, Chiba University Graduate School of Medicine, 1-8-1 Inohana, Chuo-ku, Chiba 260-8670, Japan. E-mail: htakano-cib@umin.ac.jp

All rights are reserved to the Japanese Circulation Society. For permissions, please e-mail: cj@j-circ.or.jp

\section{PPAR $\gamma$}

Peroxisome is a subcellular organelle that plays a crucial role in cellular metabolism. Peroxisome enzymes are implicated in a broad range of catabolic and anabolic enzymatic pathways, such as fatty acid oxidation, biosynthesis of both glycerolipids and cholesterol, and metabolism of reactive oxygen species. Peroxisome proliferation induced in rodents is associated with cellular responses to a range of chemical compounds. In 1990, Issemann and Green reported that peroxisome proliferators activate a member of the steroid hormone receptor superfamily in mouse liver! This nuclear receptor was named PPAR. Soon after, 3 major types of $\operatorname{PPAR}(\alpha, \beta / \delta$, and $\gamma)$ were recognized. PPAR $\gamma$ is associated with adipocyte differentiation and glucose homeostasis. PPAR $\gamma$ is expressed in a variety of cell types, including adipocytes, macrophages, vascular smooth muscle cells (VSMCs), endothelial cells (ECs), and cardiomyocytes:-7 Several lines of evidence have demonstrated the functional significance of PPAR $\gamma$ in atherosclerotic lesions 8,9

Activity of PPAR $\gamma$ is depressed by phosphorylation of a serine residue $\left(\mathrm{Ser}^{112}\right)$ in the $\mathrm{N}$-terminal domain, mediated by a member of the mitogen-activated protein (MAP) kinase family, extracellular signal-regulated protein kinase (ERK). In addition, another member of MAP kinase family, c-Jun $\mathrm{N}$-terminal kinase (JNK) also phosphorylates $\operatorname{PPAR} \gamma$ at $\mathrm{Ser}^{82}$ and reduces the transcriptional activity of PPAR $\gamma$. The association of PPAR $\gamma$ polymorphism with metabolic syndrome has also been examined!10,11 In the presence of ligand, PPAR $\gamma$ binds to coactivator complexes, resulting in the activation of target genes. In the absence of ligand, PPAR $\gamma$ binds to the promoters of several target genes and associates with a corepressor complex, leading to active repression of target genes. This process is referred to as active repression (Fig 1). The corepressor complex constitutes corepressor proteins, such as nuclear receptor corepressor 
A

Ligand-binding

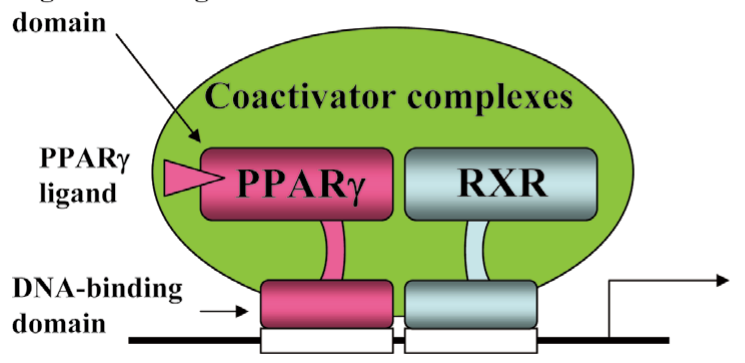

PPRE
$\mathrm{B}$

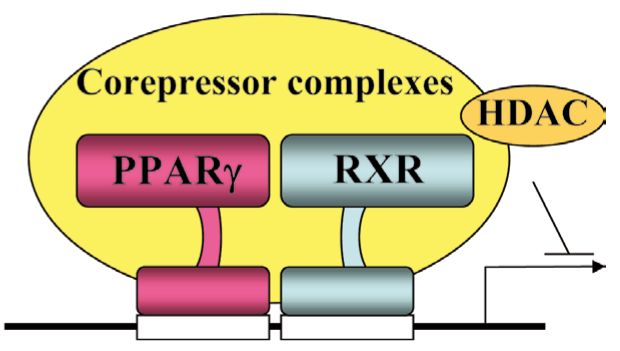

PPRE

Fig 1. Transactivation and active repression. PPAR $\gamma$ functions as a heterodimer with RXR. (A) In the presence of ligand, PPAR $\gamma$ binds to coactivator complexes, resulting in the activation of target genes. (B) In the absence of ligand, $\operatorname{PPAR} \gamma$ binds to the promoters of several target genes and associates with corepressor complexes, leading to active repression of target genes. HDAC, histone deacetylase; PPAR, peroxisome proliferator-activated receptor; PPRE, PPAR responsive element; $\mathrm{RXR}$, retinoid $\mathrm{X}$ receptor.

$(\mathrm{NCoR})$ and silencing mediator of retinoid and thyroid hormone receptors, histone deacetylases (HDACs) and transducin $\beta$-like protein 1 (TBL1). HDACs are essential in maintaining repressed chromatin structure and TBL1 exchanges a corepressor complex for a coactivator complex in the presence of ligand! ${ }^{2}$

Many nuclear receptors are proposed to sequester inflammatory transcription factors, such as nuclear factor- $\kappa \mathrm{B}$ (NF$\kappa \mathrm{B})$ and AP-1, by inhibiting their DNA-binding activities, resulting in inhibition of inflammatory target genes. In the presence of ligand, PPAR $\gamma$ also interacts with inflammatory transcription factors and inhibits their DNA-binding activities. PPAR $\gamma$ blocks clearance of the corepressor complex in a ligand-dependent manner, and PPAR $\gamma$ stabilizes the corepressor complex bound to the promoter of inflammatory genes ${ }^{13}$ It was demonstrated that PPAR $\gamma$ associates with the protein inhibitor of activated STAT1 (PIAS1), which is a small ubiquitin-like modifier (SUMO)-E3 ligase, in a liganddependent manner. PIAS1-induced SUMOylation of the ligand-binding domain of PPAR $\gamma$ enables the receptor to maintain NCoR on the promoter of inflammatory genes ${ }^{14}$ These are the suggested mechanisms of PPAR $\gamma$ transrepression.

\section{PPAR $\gamma$ Ligands}

Natural and synthetic ligands bind to PPAR $\gamma$, resulting in conformational change and activation of PPAR $\gamma$. The PGD 2 metabolite, $15 \mathrm{~d}-\mathrm{PGJ}_{2}$, was the first endogenous ligand for $\operatorname{PPAR} \gamma$ to be discovered. Although $15 \mathrm{~d}-\mathrm{PGJ} 2$ is the most potent natural ligand of PPAR $\gamma$, the extent to which its effects are mediated through PPAR $\gamma$ in vivo remains to be determined. Two components of oxidized low density lipoprotein (ox-LDL), the 9-hydroxy and 13-hydroxy octadecadienoic acids (HODE), are also potent endogenous activators of PPAR $\gamma !^{15,16}$ Activation of 12/15-lipoxygenase induced by interleukin (IL)-4 also produced endogenous ligands for PPAR $\gamma ;{ }^{17}$ however, whether these natural ligands act as physiological PPAR $\gamma$ ligands in vivo remains unknown. The antidiabetic thiazolidinediones (TZDs), such as troglitazone, pioglitazone, ciglitazone and rosiglitazone, which are used to control glucose concentration in patients with diabetes mellitus (DM), are pharmacological ligands of PPAR $\gamma$. They bind PPAR $\gamma$ with various affinities and it is conceiv- able that their insulin-sensitizing and hypoglycemic effects are exerted by activating PPAR $\gamma$. However, the molecular mechanisms by which TZDs affect insulin resistance and glucose homeostasis are not fully understood. They seem to mediate their effects primarily through adipose tissue, because TZDs alter the expression level of genes that are involved in lipid uptake, lipid metabolism and insulin action in adipocytes. TZDs enhance adipocyte insulin signaling and reduce the release of free fatty acids. TZDs also decrease the inflammation of adipose tissue that is induced by obesity and contributes to increased insulin resistance. There is a possibility that TZDs improve insulin sensitivity in skeletal muscle and liver, the main insulin-sensitive organs, through these multiple adipocentric actions. PPAR $\gamma$ has been demonstrated to have an antiinflammatory effect, leading to initiation of treatment trials for patients with inflammatory diseases. RXR, which interacts with the PPARs, is activated by 9 -cis retinoic acid. When combined as a PPAR:RXR heterodimer, the PPAR ligands and 9-cis retinoic acid act synergistically on PPAR responses.

\section{PPAR $\gamma$ and Atherosclerosis}

Atherosclerosis is a complex process to which many different factors contribute. Injury of the endothelium, proliferation of VSMCs, migration of monocytes/macrophages, and the regulatory network of growth factors and cytokines are important in the development of atherosclerosis. In addition, chronic inflammation of the vascular wall is also involved. As mentioned earlier, PPAR $\gamma$ has antiinflammatory effect. $\operatorname{PPAR} \gamma$ ligands have been shown to reduce production of inflammatory cytokines, such as IL- $1 \beta$, IL-6, inducible nitric oxide synthase and tumor necrosis factor- $\alpha$ (TNF- $\alpha$ ), by inhibiting the activity of transcription factors such as activator protein-1 (AP-1), signal transducers and activators of transcription (STAT), and NF- $\kappa \mathrm{B}$ in monocytes/macrophages ${ }^{2,3}$ Those findings suggest that PPAR $\gamma$ activation may have beneficial effects in modulating inflammatory responses in atherosclerosis. Interestingly, expression of PPAR $\gamma$ has been demonstrated in atherosclerotic plaques? Macrophages affect the vulnerability of plaque to rupture and they are implicated in the secretion of matrix metalloproteinases (MMPs), enzymes that are important in the degradation of extracellular matrix. In macrophages and VSMCs, PPAR $\gamma$ 


\section{Atherosclerosis}

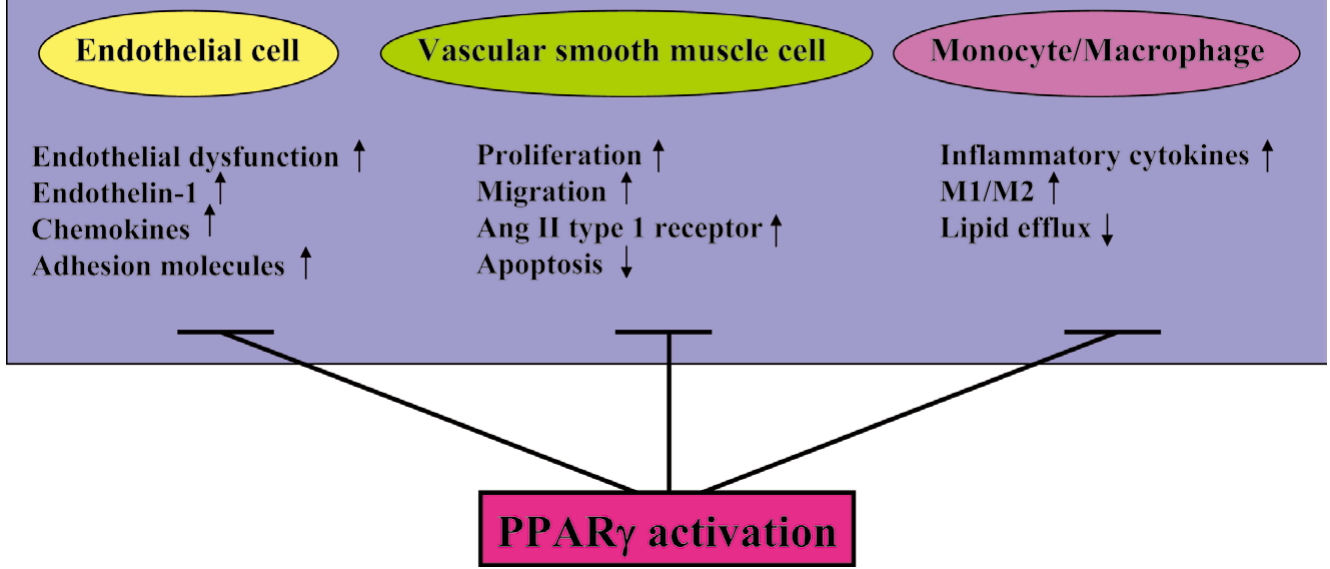

Fig 2. In atherosclerosis, PPAR $\gamma$ inhibits progression of the atherosclerotic lesion. PPAR, peroxisome proliferator-activated receptor.

ligands have been shown to reduce the expression of MMP9, resulting in the inhibition of migration of VSMCs, and plaque destabilization 3,4 Although activation of T lymphocytes represents a critical step in atherosclerosis, PPAR $\gamma$ ligands also reduce the activation $\mathrm{T}$ lymphocytes ${ }^{18}$ Recently, it was reported that PPAR $\gamma$ is a key regulator of M1/M2 polarization! ${ }^{19}$ Classically activated macrophages (M1) express a high level of pro-inflammatory cytokines and reactive oxygen species, whereas alternatively activated macrophages (M2) play an antiinflammatory role in atherosclerosis. PPAR $\gamma$ agonists prime monocytes into M2 and PPAR $\gamma$ expression is enhanced by M2 differentiation ${ }^{20}$

VSMC proliferation and migration are also critical events in atherosclerosis and vascular-intervention-induced restenosis. TZDs inhibit both these changes in the VSMCs and neointimal thickening after vascular injury ${ }^{21-24}$ Furthermore, TZDs induce apoptosis of VSMCs via p53 and Gadd4525,26 Angiotensin II (AngII) plays an important role in vascular remodeling via the AngII type 1 receptor $\left(\mathrm{AT}_{1} \mathrm{R}\right)$ and accelerates atherosclerosis. Although AngII induces transcriptional suppression of PPAR $\gamma$, activation of PPAR $\gamma$ inhibits AT 1 R gene expression at a transcriptional level in VSMCs ${ }^{27-29}$ Expression of adhesion molecule by ECs, leading to adhesion of leukocytes, is a critical early step in atherosclerosis. $\operatorname{PPAR} \gamma$ ligands inhibit the expression of vascular cell adhesion molecule-1 (VCAM-1) and intercellular adhesion molecule- 1 and decreased production of chemokines, such as IL-8 and monocyte chemotactic protein-1 (MCP-1) via suppressions of AP-1 and NF- $\kappa$ B activities in ECs ${ }^{30-32}$ PPAR $\gamma$ ligands also inhibit MCP-1-induced monocytes migration 33 Endothelin-1 (ET-1) is involved in the regulation of vascular tone and endothelial functions, and induces proliferation of VSMCs. In bovine aortic ECs, PPAR $\gamma$ ligands suppressed transcription of the ET-1 promoter by interfering with AP134

PPAR $\gamma$ activation by major oxidized lipid components of ox-LDL, 9-HODE and 13-HODE has an important role in the development of lipid-accumulating macrophages through transcriptional induction of $\mathrm{CD} 36$, a scavenger receptor 35 These findings suggest that atherogenic ox-LDL particles could induce their own uptake through activation of PPAR $\gamma$ and expression of CD36, leading to atherosclerosis. How- ever, several studies have demonstrated that activation of PPAR $\gamma$ does not promote lipid accumulation in either mouse or human macrophages ${ }^{36-38}$ Liver $\mathrm{X}$ receptor $\alpha(\mathrm{LXR} \alpha)$ is an oxysterol receptor that promotes cholesterol excretion and efflux by modulating expression of ATP-binding cassette transporter 1 (ABCA1) ? $^{37,38} \mathrm{LXR} \alpha$ was recently identified as a direct target of PPAR $\gamma$ in mouse and human macrophages 39,40 Although the PPAR $\gamma$-induced increase in CD36 expression might accelerate lipid uptake in macrophages, subsequent activation of $\operatorname{LXR} \alpha$ and upregulation of $\mathrm{ABCA} 1$ appear to induce lipid efflux.

Diep et al have demonstrated that rosiglitazone and pioglitazone attenuate the development of hypertension and structural abnormalities, and improve endothelial dysfunction in AngII-infused rats. ${ }^{41}$ These TZDs also prevented upregulation of AT 1 R, cell cycle proteins, and inflammatory mediators. Rosiglitazone, but not the PPAR $\alpha$ ligand fenofibrate, prevented hypertension and endothelial dysfunction in DOCA-salt hypertensive rats.2 It has been reported that serum levels of the soluble CD40 ligand are elevated in acute coronary syndrome and associated with increased cardiovascular risk. Treatment with rosiglitazone decreased the serum levels of soluble CD40 and MMP-9 in type 2 diabetic patients with coronary artery disease ${ }^{43}$ Taking all the evidence together, PPAR $\gamma$ ligands may prevent the progression of atherosclerotic lesions, particularly in patients with DM (Fig 2).

\section{PPAR $\gamma$ and Ischemic Heart Disease}

As the effects of PPAR $\gamma$ on the heart are not fully understood, we and others have examined whether PPAR $\gamma$ is involved in various heart diseases. Although the expression of PPAR $\gamma$ in cardiac myocytes is low compared with adipocytes, PPAR $\gamma$ ligands seem to act on cardiac myocytes. ${ }^{74}$ We demonstrated that PPAR $\gamma$ ligands inhibited the cardiac expression of TNF- $\alpha$ at the transcriptional level, in part by antagonizing NF- $\kappa$ B activity? Because TNF- $\alpha$ expression is elevated in the failing heart and has a negative inotropic effect on cardiac myocytes, treatment with PPAR $\gamma$ ligands may prevent the development of congestive heart failure. Diabetic cardiomyopathy, which is characterized by 


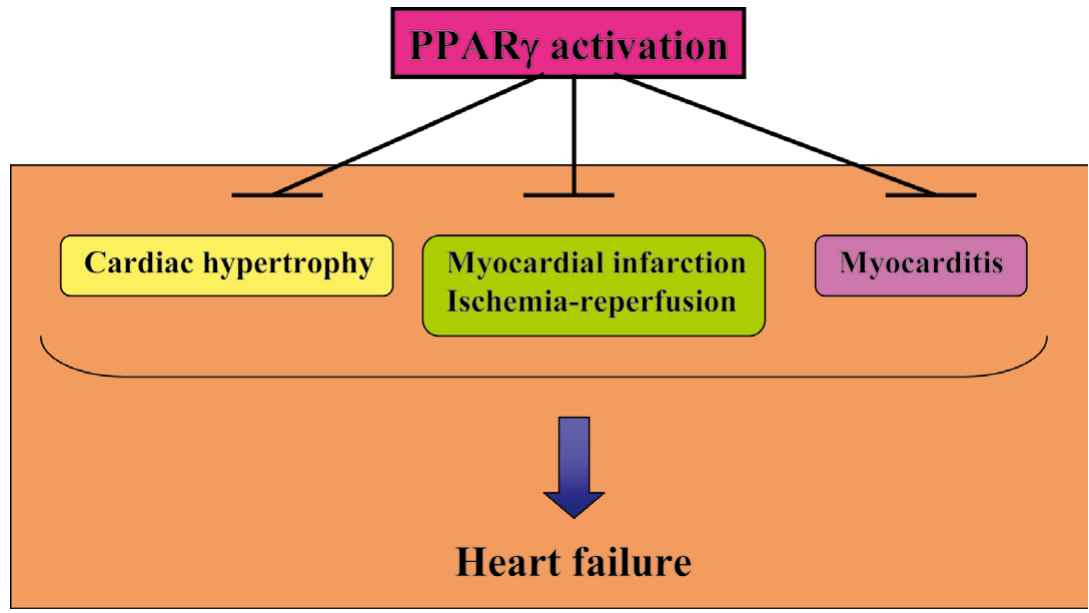

Fig 3. Actions of PPAR $\gamma$ in heart diseases. PPAR $\gamma$ inhibits the progression of heart failure following cardiac hypertrophy, myocardial infarction, ischemia-reperfusion injury, and myocarditis. PPAR, peroxisome proliferatoractivated receptor. systolic and diastolic dysfunction, is a major complication of DM, and therefore TZDs seem to be beneficial for the impaired cardiac function in patients with DM. Following our study, the role of PPAR $\gamma$ in myocardial ischemia-reperfusion (IR) injury has been elucidated.5-48 In animal models, PPAR $\gamma$ ligands reduced the size of the myocardial infarct and improved contractile dysfunction after IR through inhibition of the inflammatory response. IR injury activates JNK, and subsequently JNK induces increases in both AP-1 DNA-binding activity and apoptotic cells. It has been shown in rats that rosiglitazone inhibits the activation of JNK and AP-1 after myocardial IR 46 Furthermore, pioglitazone has been reported to attenuate left ventricular remodeling and heart failure after myocardial infarction (MI) in mice. ${ }^{4}$ Both of these effects of TZDs ligands were associated with decreases in inflammatory cytokines and chemokines.9,50

\section{PPAR $\gamma$ and Cardiac Hypertrophy}

The PPAR $\gamma$ ligands, troglitazone, pioglitazone and rosiglitazone, inhibited AngII-induced hypertrophy of neonatal rat cardiac myocytes ${ }^{51-53}$ Because generalized PPAR $\gamma$ gene deletion causes embryonic lethality, we examined the role of PPAR $\gamma$ in the development of cardiac hypertrophy in vivo using heterozygous PPAR $\gamma$-deficient $\left(\operatorname{PPAR} \gamma^{+/-}\right)$ mice 53 Pressure overload-induced cardiac hypertrophy was more prominent in heterozygous $\operatorname{PPAR} \gamma^{+/-}$mice than in wild-type (WT) mice. Treatment with pioglitazone strongly inhibited the pressure overload-induced cardiac hypertrophy in WT mice and moderately in PPAR $\gamma^{+/-}$mice 53 Thereafter, 2 other groups examined the role of PPAR $\gamma$ in the heart by using cardiomyocyte-specific PPAR $\gamma$ knockout mice ${ }^{4,55}$ Duan et al reported that these mice develop cardiac hypertrophy through elevated $\mathrm{NF}-\kappa \mathrm{B}$ activity ${ }^{54}$ and unexpectedly, rosiglitazone induced cardiac hypertrophy in both the WT mice and cardiomyocyte-specific PPAR $\gamma$ knockout mice through activation of p38 MAP kinase independent of $\operatorname{PPAR} \gamma$. Ding et al reported that cardiomyocyte-specific PPAR $\gamma$ knockout mice displayed cardiac hypertrophy from approximately 3 months of age and then progress to dilated cardiomyopathy; $; 5$ most mice died from heart failure within 1 year after birth. Mitochondrial oxidative damage and reduced expression of manganese superoxide dismutase were recognized in the cardiomyocyte-specific PPAR $\gamma$ knockout mice 55 These mice models demonstrate that PPAR $\gamma$ is essential for protecting cardiomyocytes from stress and oxidative damage, although the expression level of PPAR $\gamma$ in cardiomyocytes is low. On the other hand, Son et al demonstrated that cardiomyocyte-specific PPAR $\gamma$ transgenic mice develop dilated cardiomyopathy associated with increased uptake of both fatty acid and glucose 56 Rosiglitazone increased this glucolipotoxicity in cardiomyocytespecific PPAR $\gamma$ transgenic mice. If PPAR $\gamma$ in the heart is expressed at a high level, rosiglitazone may cause cardiotoxic effects; however, as noted earlier the expression level of PPAR $\gamma$ in the heart is quite low.

\section{PPAR $\gamma$ and Myocarditis}

Experimental autoimmune myocarditis (EAM) is a Tcell-mediated disease characterized by infiltration of T cells and macrophages, leading to massive myocarditis necrosis, which develops into heart failure in the chronic phase. ${ }^{57}$ The onset of EAM in rats occurs approximately 2 weeks after the first immunization with porcine cardiac myosin. At this time, small numbers of CD4+ $\mathrm{T}$ cells and macrophages start to infiltrate into the myocardium and various cytokines are expressed. Macrophage inflammatory protein- $1 \alpha$ (MIP$1 \alpha$ ) is a C-C chemokine that induces leukocyte accumulation in tissue sites of inflammation. We previously demonstrated that MIP- $1 \alpha$ mRNA and protein are highly expressed in the hearts of rats with EAM from day 11 after first immunization 57 Th1 cells produce interferon- $\gamma(\mathrm{IFN}-\gamma)$, which is mainly involved in cell-mediated immune responses, whereas Th2 cells produce IL-4, IL-5, IL-6, IL-10 and IL-13, which participate in humoral responses. Immune dysfunction associated with autoimmune disease is known to involve an imbalance between Th1 and Th2 cells.

It has been reported that pioglitazone treatment markedly reduces the severity of myocarditis in a rat model of EAM58,59 Pioglitazone suppressed expression of inflammatory cytokines and activation of myocardiogenic T cells in the myocardium of EAM rats58 The mRNA levels of MIP- $1 \gamma$ were upregulated in the hearts of EAM rats, but not in the hearts of those in the pioglitazone group. Furthermore, treatment with pioglitazone decreased the expression levels of pro-inflamatory cytokine (TNF- $\alpha$ and IL-1 $\beta$ ) genes and Th1 cytokine (IFN- $\gamma$ ) genes, and increased the expression levels of Th2 cytokine (IL-4) gene ${ }^{9}$ These results suggest that PPAR $\gamma$ ligands may have beneficial effects on myocarditis by inhibiting MIP- $1 \alpha$ expression and modulating the Th1/Th2 balance (Fig 3). 


\section{Efficacy and Safety of TZD Treatment in the Clinical Setting}

Despite the beneficial effects of TZDs in the basic experiments, their propensity to cause fluid retention is a serious side-effect. Clinical studies report TZD-induced peripheral fluid retention, and an increase in plasma volume in $2-5 \%$ of patients on monotherapy 60 Fluid retention was more likely to occur with concomitant insulin use, and in patients with underlying cardiac dysfunction or renal insufficiency. The exact mechanisms for TZD-induced fluid retention are not well understood, and it remains unclear whether TZDs directly cause the development of de novo congestive heart failure. It is known that the level of vascular endothelial growth factor is increased in the patients who develop fluid retention with TZD therapy ${ }^{61}$ and this may lead to peripheral edema through increased vascular permeability. The insulin-sensitizing action of TZDs also induces water and salt retention. PPAR $\gamma$ is highly expressed in the kidney and collecting-duct-specific PPAR $\gamma$ knockout mice demonstrated no effects of TZD on fluid retention or the expression level of sodium channel ENaC- $\gamma^{62,63}$ These findings suggest that activation of the sodium channel in the collecting duct cells expressing PPAR $\gamma$ may be a mechanism of fluid retention. In patients without evidence of heart failure, careful examination did not reveal any worsening of left ventricular function by TZDs 64 There are very few studies investigating the safety of TZDs in patients with preexisting heart failure. Although a recent study demonstrated that there is not a direct association between the risk of fluid retention and the baseline degree of severity of heart failure in diabetic patients treated with TZDs, the prescription of TZDs for patients with established heart failure should be avoided at present ${ }^{60,65}$

The PROactive (Prospective Pioglitazone Clinical Trial in Macrovascular Events) study has shown that pioglitazone significantly decreases the occurrence of all-cause mortality, nonfatal MI, and nonfatal stroke in patients with type $2 \mathrm{DM}$ and macrovascular diseases 66 Pioglitazone significantly reduced the occurrence of fatal and nonfatal MI by $28 \%$ in the PROactive study66 Although there was a $1.6 \%$ absolute increase in heart failure hospitalizations in the pioglitazone group compared with the placebo group, the number of heart-failure-related deaths was almost identical. In contrast to the PROactive study, it has been recently reported that rosiglitazone treatment is associated with increased incidence of MI by meta-analysis ${ }^{67,68}$ Although meta-analysis has a number of limitations and the increased risk in MI is still controversial, those results attracted the attention of many clinicians. There are some differences in the actions of pioglitazone and rosiglitazone. Pioglitazone has more beneficial effects on the lipid profile than rosiglitazone 69 As mentioned earlier, rosiglitazone, but not pioglitazone, induced cardiac hypertrophy by a non-PPAR $\gamma$-mediated pathway ${ }^{54}$ Pioglitazone represses $\mathrm{NF}-\kappa \mathrm{B}$ activation and VCAM-1 expression in a PPAR $\alpha$-dependent manner? ${ }^{7}$ Pioglitazone was recently reported to increase the number and function of endothelial progenitor cells (EPCs) in patients with stable coronary artery disease and normal glucose tolerance ${ }^{71}$ Pioglitazone may induce angiogenesis by modulating EPC mobilization and function. In the future, more mechanistic studies are required to investigate the differences in action between pioglitazone and rosiglitazone.

\section{Conclusions}

The American Heart Association (AHA) and American Diabetes Association (ADA) have released a consensus statement that advises caution regarding the use of TZDs in patients with known or suspected heart failure?2 Because there is a possibility that TZDs may unmask asymptomatic cardiac dysfunction by increasing plasma volume, they should be avoided in patients with congestive heart failure of New York Heart Association (NYHA) class III or IV. The data from in vitro studies suggest that TZDs exert direct actions on vascular cells and cardiomyocytes, independent of their glucose-mediated mechanisms. Further studies using tissue-specific gene targeting mice are necessary to address in vivo the pleiotropic effects of PPAR $\gamma$ on the cardiovascular system. If the beneficial roles of PPAR $\gamma$ can be solved, modulation of PPAR $\gamma$ may become a promising therapeutic strategy for cardiovascular diseases. Because cardiac hypertrophy can be seen even in normotensive diabetic patients, and diabetic cardiomyopathy is a major complication of DM, antidiabetic agents such as the TZDs would be expected to have beneficial effects on cardiac hypertrophy and dysfunction in patients with DM. It has been already clarified that 3-hydroxy-3-methyglutaryl-coenzyme A reductase inhibitors, statins, have pleiotropic effects in cardiovascular diseases. The effects of PPAR $\gamma$ ligands are similar to those of statins in many respects. A recent study demonstrated that statins activate PPAR $\gamma$ through ERK and p38 MAP-kinase-dependent cyclooxygenase-2 expression in macrophages ${ }^{73}$ Further studies are needed to elucidate the molecular mechanisms of the pleiotropic effects of PPAR $\gamma$ ligands in cardiovascular disease.

\section{Acknowledgments}

This work was supported by grants from the Ministry of Education, Culture, Sports, Science and Technology in Japan, Takeda Science Foundation, and Mitsui Life Social Welfare Foundation.

\section{References}

1. Issemann I, Green S. Activation of a member of the steroid hormone receptor superfamily by peroxisome proliferators. Nature 1990; 347: 645-650.

2. Jiang C, Ting AT, Seed B. PPAR- $\gamma$ agonists inhibit production of monocyte inflammatory cytokines. Nature 1998; 391: 82-86.

3. Ricote M, Li AC, Willson TM, Kelly CJ, Glass CK. The peroxisome proliferator-activated receptor- $\gamma$ is a negative regulator of macrophage activation. Nature 1998; 391: 79-82.

4. Marx N, Schonbeck U, Lazar MA, Libby P, Plutzky J. Peroxisome proliferator-activated receptor $\gamma$ activators inhibit gene expression and migration in human vascular smooth muscle cells. Circ Res 1998; 83: $1097-1103$.

5. Iijima K, Yoshizumi M, Ako J, Eto M, Kim S, Hashimoto M, et al. Expression of peroxisome proliferator-activated receptor $\gamma(\operatorname{PPAR} \gamma)$ in rat aortic smooth muscle cells. Biochem Biophys Res Commun 1998; 247: 353-356.

6. Benson S, Wu J, Padmanabhan S, Kurtz TW, Pershadsingh HA. Peroxisome proliferator-activated receptor (PPAR) $-\gamma$ expression in human vascular smooth muscle cells: Inhibition of growth, migration, and c-fos expression by the peroxisome proliferator-activated receptor (PPAR)- $\gamma$ activator troglitazone. Am J Hypertens 2000; 13: $74-82$.

7. Takano H, Nagai T, Asakawa M, Toyozaki T, Oka T, Komuro I, et al. Peroxisome proliferator-activated receptor activators inhibit lipopolysaccharide-induced tumor necrosis factor- $\alpha$ expression in neonatal rat cardiac myocytes. Circ Res 2000; 87: 596-602.

8. Marx N, Sukhova G, Murphy C, Libby P, Plutzky J. Macrophage in human atheroma contain PPAR $\gamma$ : Differentiation-dependent peroxisomal proliferator-activated receptor $\gamma(\operatorname{PPAR} \gamma)$ expression and reduction of MMP-9 activity through PPAR $\gamma$ activation in mononuclear phagocytes in vitro. Am J Pathol 1998; 153: 17-23. 
9. Ricote M, Huang J, Fajas L, Li A, Welch J, Najib J, et al. Expression of the peroxisome proliferator-activated receptor $\gamma(\operatorname{PPAR} \gamma)$ in human atherosclerosis and regulation in macrophages by colony stimulating factors and oxidized low density lipoprotein. Proc Natl Acad Sci USA 1998; 95: 7614-7619.

10. Rhee EJ, Kwon CH, Lee WY, Kim SY, Jung CH, Kim BJ, et al. No association of Pro12Ala polymorphism of PPAR-gamma gene with coronary artery disease in Korean subjects. Circ J 2007; 71: 338 342.

11. Dongxia L, Qi H, Lisong L, Jincheng G. Association of peroxisome proliferator-activated receptor $\gamma$ gene Pro12Ala and C161T polymorphisms with metabolic syndrome. Circ J 2007; 72: 551-557.

12. Perissi V, Aggarwal A, Glass CK, Rose DW, Rosenfeld MG. A corepressor/coactivator exchange complex required for transcriptional activation by nuclear receptors and other regulated transcription factors. Cell 2004; 116: 511-526.

13. Ogawa S, Lozach J, Jepsen K, Sawka-Verhelle D, Perissi V, Sasik R, et al. A nuclear receptor corepressor transcriptional checkpoint controlling activator protein 1-dependent gene networks required for macrophage activation. Proc Natl Acad Sci USA 2004; 101: 14461 14466

14. Pascual G, Fong AL, Ogawa S, Gamliel A, Li AC, Perissi V, et al. A SUMOylation-dependent pathway mediates transrepression of inflammatory response genes by PPAR-gamma. Nature 2005; 437: 759763.

15. Nagy L, Tontonoz P, Alvarez JGA, Chen H, Evans RM. Oxidized LDL regulates macrophage gene expression through ligand activation of PPAR $\gamma$. Cell 1998; 93: 229-240.

16. Tontonoz P, Nagy L, Alvarez JGA, Thomazy VA, Evans RM. PPAR $\gamma$ promotes monocyte/macrophage differentiation and uptake of oxidized LDL. Cell 1998; 93: 241-252.

17. Huang JT, Welch JS, Ricote M, Binder CJ, Willson TM, Kelly C, et al. Interleukin-4-dependent production of PPAR- $\gamma$ ligands in macrophages by 12/15-lipoxygenase. Nature 1999; 400: 378-382.

18. Marx N, Kehrle B, Kohlhammer K, Grub M, Koenig W, Hombach $\mathrm{V}$, et al. PPAR activators as antiinflammatory mediators in human $\mathrm{T}$ lymphocytes: Implications for atherosclerosis and transplantationassociated arteriosclerosis. Circ Res 2002; 90: 703-710.

19. Bouhlel MA, Derudas B, Rigamonti E, Dièvart R, Brozek J, Haulon $\mathrm{S}$, et al. PPAR $\gamma$ activation primes human monocytes into alternative M2 macrophages with anti-inflammatory properties. Cell Metab 2007; 6: $137-143$.

20. Odegaard JI, Ricardo-Gonzalez RR, Goforth MH, Morel CR, Subramanian V, Mukundan L, et al. Macrophage-specific PPAR $\gamma$ controls alternative activation and improves insulin resistance. Nature 2007; 447: 1116-1120.

21. Law RE, Meehan WP, Xi XP, Graf K, Wuthrich DA, Coats W, et al. Troglitazone inhibits vascular smooth muscle cell growth and intimal hyperplasia. J Clin Invest 1996; 98: 1897-1905.

22. Goetze S, Xi X P, Kawano H, Gotlibowski T, Fleck E, Hsueh WA, et al. PPAR $\gamma$-ligands inhibit migration mediated by multiple chemoattractants in vascular smooth muscle cells. J Cardiovasc Pharmacol 1999; 33: 798-806.

23. Hsueh WA, Jackson S, Law RE. Control of vascular cell proliferation and migration by PPAR- $\gamma$ : A new approach to the macrovascular complications of diabetes. Diabetes Care 2001; 24: 392-397.

24. Takata Y, Kitami Y, Okura T, Hiwada K. Peroxisome proliferatoractivated receptor- $\gamma$ activation inhibits interleukin- $\beta$-mediated platelet-derived growth factor- $\alpha$ receptor gene expression via CCAAT/ enhancer-binding protein- $\delta$ in vascular smooth muscle cells. J Biol Chem 2001; 276: $12893-12897$.

25. Okura T, Nakamura M, Takata Y, Watanabe S, Kitami Y, Hiwada K. Troglitazone induces apoptosis via the p53 and Gadd45 pathway in vascular smooth muscle cells. Eur J Pharmacol 2000; 407: 227 235.

26. Aizawa Y, Kawabe J, Hasebe N, Takehara N, Kikuchi K. Pioglitazone enhances cytokine-induced apoptosis in vascular smooth muscle cells and reduces intimal hyperplasia. Circulation 2001; 104: 455460 .

27. Sugawara A, Takeuchi K, Uruno A, Ikeda Y, Arima S, Kudo M, et al. Transcriptional suppression of type 1 angiotensin II receptor gene expression by peroxisome proliferator-activated receptor- $\gamma$ in vascular smooth muscle cells. Endocrinology 2001; 142: 3125-3134.

28. Takeda K, Ichiki T, Tokunou T, Funakoshi Y, Iino N, Hirano K, et al. Peroxisome proliferator-activated receptor $\gamma$ activators downregulate angiotensin II type 1 receptor in vascular smooth muscle cells. Circulation 2000; 102: 1834-1839.

29. Tham DM, Martin-McNulty B, Wang YX, Wilson DW, Vergona R, Sullivan ME, et al. Angiotensin II is associated with activation of NF- $\kappa$ B-mediated genes and downregulation of PPARs. Physiol
Genomics 2002; 11: 21-30.

30. Jackson SM, Parhami F, Xi XP, Berliner JA, Hsueh WA, Law RE, et al. Peroxisome proliferator-activated receptor activators target human endothelial cells to inhibit leukocyte-endothelial cell interaction. Arterioscler Thromb Vasc Biol 1999; 19: 2094-2104.

31. Pasceri V, Wu HD, Willerson JT, Yeh ETH. Modulation of vascular inflammation in vitro and in vivo by peroxisome proliferator-activated receptor- $\gamma$ activators. Circulation 2000; 101: 235-238.

32. Lee H, Shi W, Tontonoz P, Wang S, Subbanagounder G, Hedrick $\mathrm{CC}$, et al. Role of peroxisome proliferator-activated receptor $\alpha$ in oxidized phospholipid-induced synthesis of monocyte chemotactic protein-1 and interleukin-8 by endothelial cells. Circ Res 2000; 87: $516-521$.

33. Kintscher U, Goetze S, Wakino S, Kim S, Nagpal S, Chandraratna $\mathrm{RA}$, et al. Peroxisome proliferator-activated receptor and retinoid $\mathrm{X}$ receptor ligands inhibit monocyte chemotactic protein-1-directed migration of monocytes. Eur J Pharmacol 2000; 401: 259-270.

34. Delerive P, Martin-Nizard F, Chinetti G, Trottein F, Fruchart JC, Najib J, et al. Peroxisome proliferator-activated receptor activators inhibit thrombin-induced endothelin-1 production in human vascular endothelial cells by inhibiting the activator protein-1 signaling pathway. Circ Res 1999; 85: 394-402.

35. Han J, Hajjar DP, Tauras JM, Feng J, Gotto AM Jr, Nicholson AC. Transforming growth factor- $\beta 1$ (TGF- $\beta 1$ ) and TGF- $\beta 2$ decrease expression of $\mathrm{CD} 36$, the type $\mathrm{B}$ scavenger receptor, through mitogenactivated protein kinase phosphorylation of peroxisome proliferatoractivated receptor- $\gamma$. J Biol Chem 2000; 275: $1241-1246$.

36. Repa JJ, Turley SD, Lobaccaro JA, Medina J, Li L, Lustig K, et al. Regulation of absorption and ABC1-mediated efflux of cholesterol by RXR heterodimers. Science 2000; 289: 1524-1529.

37. Venkateswaran A, Laffitte BA, Joseph SB, Mak PA, Wilpitz DC, Edwards PA, et al. Control of cellular cholesterol efflux by the nuclear oxysterol receptor LXR alpha. Proc Natl Acad Sci USA 2000; 97: 12097-12102.

38. Costet P, Luo Y, Wang N, Tall AR. Sterol-dependent transactivation of the $\mathrm{ABC} 1$ promoter by the liver $\mathrm{X}$ receptor/retinoid $\mathrm{X}$ receptor. J Biol Chem 2000; 275: 28240-28245.

39. Chawla A, Boisvert WA, Lee CH, Laffitte BA, Barak Y, Joseph SB, et al. A PPAR $\gamma$-LXR-ABCA1 pathway in macrophages is involved in cholesterol efflux and atherogenesis. Mol Cell 2001; 7: 161-171.

40. Chinetti G, Lestavel S, Bocher V, Remaley AT, Neve B, Torra IP, et al. PPAR- $\alpha$ and PPAR- $\gamma$ activators induce cholesterol removal from human macrophage foam cells through stimulation of the ABCA1 pathway. Nat Med 2001; 7: 53-58.

41. Diep QN, El Mabrouk M, Cohn JS, Endemann D, Amiri F, Virdis A, et al. Structure, endothelial function, cell growth, and inflammation in blood vessels of angiotensin II-infused rats: Role of peroxisome proliferator-activated receptor- $\gamma$. Circulation 2002; 105: 2296-2302.

42. Iglarz M, Touyz RM, Amiri F, Lavoie MF, Diep QN, Schiffrin EL. Effect of peroxisome proliferator-activated receptor- $\alpha$ and $-\gamma$ activators on vascular remodeling in endothelin-dependent hypertension. Arterioscler Thromb Vasc Biol 2003; 23: 45-51.

43. Marx N, Imhof A, Froehlich J, Siam L, Ittner J, Wierse G, et al. Effect of rosiglitazone treatment on soluble CD40L in patients with type 2 diabetes and coronary artery disease. Circulation 2003; 107: $1954-1957$.

44. Mehrabi MR, Thalhammer T, Haslmayer P, Glogar HD, Wieselthaler $\mathrm{G}$, Humpeler S, et al. The peroxisome proliferator-activated receptor $\gamma$ $(\operatorname{PPAR} \gamma)$ is highly expressed in human heart ventricles. Biomed Pharmacother 2002; 56: 407-410.

45. Yue T, Chen J, Bao W, Narayanan PK, Bril A, Jiang W, et al. In vivo myocardial protection from IR injury by the peroxisome proliferatoractivated receptor- $\gamma$ agonist rosiglitazone. Circulation 2001; 104: $2588-2594$.

46. Khandoudi N, Delerive P, Berrebi-Bertrand I, Buckingham RE, Staels B, Bril A. Rosiglitazone, a peroxisome proliferator-activated receptor- $\gamma$, inhibits the Jun $\mathrm{NH}(2)$-terminal kinase/activating protein 1 pathway and protects the heart from IR injury. Diabetes 2002; 51: $1507-1514$

47. Wayman NS, Hattori Y, McDonald MC, Mota-Filipe H, Cuzzocrea $\mathrm{S}$, Pisano B, et al. Ligands of the peroxisome proliferator-activated receptors (PPAR- $\gamma$ and PPAR- $\alpha$ ) reduce myocardial infarct size. FASEB J 2002; 16: 1027-1040.

48. Zhu P, Lu L, Xu Y, Schwartz GG. Troglitazone improves recovery of left ventricular function after regional ischemia in pigs. Circulation 2000; 101: $1165-1171$.

49. Shiomi T, Tsutsui H, Hayashidani S, Suematsu N, Ikeuchi M, Wen J, et al. Pioglitazone, a Peroxisome proliferator-activated receptor- $\gamma$ agonist, attenuates left ventricular remodeling and failure after experimental myocardial infarction. Circulation 2002; 106: 3126-3132. 
50. Ikejima H, Imanishi T, Tsujioka H, Kuroi A, Muragaki Y, Mochizuki $\mathrm{S}$, et al. Effect of pioglitazone on nitroglycerin-induced impairment of nitric oxide bioavailability by a catheter-type nitric oxide sensor. Circ J 2008; 72: 998-1002.

51. Takano H, Zou Y, Akazawa H, Toko H, Mizukami M, Hasegawa H, et al. Inhibitory molecules in signal transduction pathways of cardiac hypertrophy. Hypertens Res 2002; 25: 491-498.

52. Yamamoto K, Ohki R, Lee RT, Ikeda U, Shimada K. Peroxisome proliferator-activated receptor $\gamma$ activators inhibit cardiac hypertrophy in cardiac myocytes. Circulation 2001; 104: 1670-1675.

53. Asakawa M, Takano H, Nagai T, Uozumi H, Hasegawa H, Kubota N, et al. Peroxisome proliferator-activated receptor $\gamma$ plays a critical role in inhibition of cardiac hypertrophy in vitro and in vivo. Circulation 2002; 105: $1240-1246$

54. Duan SZ, Ivashchenko CY, Russell MW, Milstone DS, Mortensen RM. Cardiomyocyte-specific knockout and agonist of peroxisome proliferator-activated receptor- $\gamma$ both induce cardiac hypertrophy in mice. Circ Res 2005; 97: 372-379.

55. Ding G, Fu M, Qin Q, Lewis W, Kim HW, Fukai T, et al. Cardiac peroxisome proliferator-activated receptor $\gamma$ is essential in protecting cardiomyocytes from oxidative damage. Cardiovasc Res 2007; 76: 269-279.

56. Son NH, Park TS, Yamashita H, Yokoyama M, Huggins LA, Okajima $\mathrm{K}$, et al. Cardiomyocyte expression of PPAR $\gamma$ leads to cardiac dysfunction in mice. J Clin Invest 2007; 117: 2791 - 2801.

57. Toyozaki T, Saito T, Shiraishi H, Tsukamoto Y, Takano H, Nagai T, et al. Macrophage inflammatory protein- $1 \alpha$ relates to the recruitment of inflammatory cells in myosin-induced autoimmune myocarditis in rats. Lab Invest 2001; 81: 929-936.

58. Yuan Z, Liu Y, Liu Y, Zhang J, Kishimoto C, Wang Y, et al. Peroxisome proliferation-activated receptor- $\gamma$ ligands ameliorate experimental autoimmune myocarditis. Cardiovasc Res 2003; 59: 685 694.

59. Hasegawa H, Takano H, Zou Y, Qin Y, Hizukuri K, Odaka K, et al. Pioglitazone, a peroxisome proliferator-activated receptor $\gamma$ activator, ameliorates experimental autoimmune myocarditis by modulating Th1/Th2 balance. J Mol Cell Cardiol 2005; 38: 257-265.

60. Wang CH, Weisel RD, Liu PP, Fedak PW, Verma S. Glitazones and heart failure: Critical appraisal for the clinician. Circulation 2003; 107: $1350-1354$

61. Sotiropoulos KB, Clermont A, Yasuda Y, Rask-Madsen C, Mastumoto M, Takahashi J, et al. Adipose-specific effect of rosiglitazone on vascular permeability and protein kinase $\mathrm{C}$ activation: Novel mechanism for PPAR $\gamma$ agonist's effects on edema and weight gain. FASEB J 2006; 20: 1203-1205

62. Zhang H, Zhang A, Kohan DE, Nelson RD, Gonzalez FJ, Yang T. Collecting duct-specific deletion of peroxisome proliferator-activated receptor $\gamma$ blocks thiazolidinedione-induced fluid retention. Proc
Natl Acad Sci USA 2005; 102: 9406-9411.

63. Guan Y, Hao C, Cha DR, Rao R, Lu W, Kohan DE, et al. Thiazolidinediones expand body fluid volume through PPAR $\gamma$ stimulation of ENaC-mediated renal salt absorption. Nat Med 2005; 11: 861-866.

64. St John Sutton M, Rendell M, Dandona P, Dole JF, Murphy K, Patwardhan R, et al. A comparison of the effects of rosiglitazone and glyburide on cardiovascular function and glycemic control in patients with type 2 diabetes. Diabetes Care 2002; 25: 2058-2064.

65. Tang WH, Francis GS, Hoogwerf BJ, Young JB. Fluid retention after initiation of thiazolidinedione therapy in diabetic patients with established chronic heart failure. J Am Coll Cardiol 2003; 41: 1394 1398.

66. Dormandy JA, Charbonnel B, Eckland DJ, Erdmann E, MassiBenedetti M, Moules IK, et al. Secondary prevention of macrovascular events in patients with type 2 diabetes in the PROactive Study (PROspective pioglitAzone Clinical Trial In macroVascular Events): A randomised controlled trial. Lancet 2005; 366: 1279-1289.

67. Nissen SE, Wolski K. Effect of rosiglitazone on the risk of myocardial infarction and death from cardiovascular causes. $N$ Engl J Med 2007; 356: $2457-2471$.

68. Singh S, Loke YK, Furberg CD. Long-term risk of cardiovascular events with rosiglitazone: A meta-analysis. JAMA 2007; 298: 1189_1195.

69. Goldberg RB, Kendall DM, Deeg MA, Buse JB, Zagar AJ, Pinaire $\mathrm{JA}$, et al. A comparison of lipid and glycemic effects of pioglitazone and rosiglitazone in patients with type 2 diabetes and dyslipidemia. Diabetes Care 2005; 28: $1547-1554$.

70. Orasanu G, Ziouzenkova O, Devchand PR, Nehra V, Hamdy O, Horton ES, et al. The peroxisome proliferator-activated receptor- $\gamma$ agonist pioglitazone represses inflammation in a peroxisome proliferator-activated receptor- $\alpha$-dependent manner in vitro and in vivo in mice. J Am Coll Cardiol 2008; 52: 869-881.

71. Werner C, Kamani CH, Gensch C, Böhm M, Laufs U. The peroxisome proliferator-activated receptor- $\gamma$ agonist pioglitazone increases number and function of endothelial progenitor cells in patients with coronary artery disease and normal glucose tolerance. Diabetes 2007; 56: $2609-2615$.

72. Nesto RW, Bell D, Bonow RO, Fonseca V, Grundy SM, Horton ES, et al. Thiazolidinedione use, fluid retention, and congestive heart failure: A consensus statement from the American Heart Association and American Diabetes Association. Circulation 2003; 108: 2941 2948.

73. Yano M, Matsumura T, Senokuchi T, Ishii N, Murata Y, Taketa K, et al. Statins activate peroxisome proliferator-activated receptor $\gamma$ through extracellular signal-regulated kinase $1 / 2$ and p38 mitogen-activated protein kinase-dependent cyclooxygenase- 2 expression in macrophages. Circ Res 2007; 100: $1442-1451$. 